Article

\title{
Subcritical Water Extraction of Valuable Metals from Spent Lithium-Ion Batteries
}

\author{
Jenni Lie, Stefani Tanda and Jhy-Chern Liu * \\ Department of Chemical Engineering, National Taiwan University of Science and Technology, 43 Keelung Road, \\ Section 4, Taipei 106, Taiwan; d10706801@mail.ntust.edu.tw (J.L.); stefanitanda@yahoo.co.id (S.T.) \\ * Correspondence: liu1958@mail.ntust.edu.tw
}

Academic Editors: Jelena Vladić and Stela Jokić

Received: 22 April 2020; Accepted: 30 April 2020; Published: 6 May 2020

check for updates

\begin{abstract}
The leaching of valuable metals ( $\mathrm{Co}, \mathrm{Li}$, and $\mathrm{Mn}$ ) from spent lithium-ion batteries (LIBs) was studied using subcritical water extraction (SWE). Two types of leaching agents, hydrochloric acid $(\mathrm{HCl})$ and ascorbic acid, were used, and the effects of acid concentration and temperature were investigated. Leaching efficiency of metals increased with increasing acid concentration and temperature. Ascorbic acid performed better than $\mathrm{HCl}$, which was attributed to ascorbic acid's dual functions as an acidic leaching agent and a reducing agent that facilitates leaching reactions, while $\mathrm{HCl}$ mainly provides acidity. The chemical analysis of leaching residue by $\mathrm{X}$-ray photoelectron spectroscopy (XPS) revealed that Co(III) oxide could be totally leached out in ascorbic acid but not in $\mathrm{HCl}$. More than $95 \%$ of $\mathrm{Co}, \mathrm{Li}$, and $\mathrm{Mn}$ were leached out from spent LIBs' cathode powder by SWE using $0.2 \mathrm{M}$ of ascorbic acid within $30 \mathrm{~min}$ at $100^{\circ} \mathrm{C}$, initial pressure of $10 \mathrm{bar}$, and solid-to-liquid ratio of $10 \mathrm{~g} / \mathrm{L}$. The application of SWE with a mild concentration of ascorbic acid at $100{ }^{\circ} \mathrm{C}$ could be an alternative process for the recovery of valuable metal in spent LIBs. The process has the advantages of rapid reaction rate and energy efficiency that may benefit development of a circular economy.
\end{abstract}

Keywords: ascorbic acid; hydrochloric acid (HCl); leaching; Li-ion batteries (LIBs); subcritical water extraction (SWE); waste

\section{Introduction}

Lithium-ion batteries (LIBs) are the main choice as the electrochemical power source for most portable electronic devices and electric vehicles (EVs). The rapid development of and high demand for electronic devices and EVs have caused the rapid increase of both the number of spent LIBs as well as the demand for metal resources, especially lithium $(\mathrm{Li})$ and cobalt $(\mathrm{Co})$. More than one million EVs worldwide were sold in 2017, which is estimated to generate around 250,000 tons of battery waste when they reach their end of life [1]. Besides which, the organic electrolytes and heavy metals in spent LIBs are toxic, which could be a risk for human health and the environment if the spent LIBs are disposed of in landfill [2,3]. Meanwhile, a huge gap between market supply and demand leads to an increase in the price of critical metals, especially for Li and Co [4]. The spent LIBs have gained a lot of attention as an urban mining source of valuable metals such as $\mathrm{Li}, \mathrm{Co}, \mathrm{Ni}, \mathrm{Al}$, and $\mathrm{Mn}$. The recovery of valuable metals from spent LIBs is essential to avoid a negative environmental impact and to ensure the safe supply of the corresponding materials [5].

Numerous studies on the recycling of spent LIBs using hydrometallurgy, pyrometallurgy, and biometallurgy have been reported. Pyrometallurgical processes have been adopted and commercialized for valuable metal recycling [6], however, high energy consumption and toxic gas emissions are the main problems of these processes. Hydrometallurgical methods are under study for recycling of spent LIBs due to the mild reaction conditions, environmental friendliness (non-toxic emissions), and high recovery efficiency of valuable metals [7]. They have been developed for metals extraction from spent 
LIBs using inorganic acids such as $\mathrm{HCl}$ and $\mathrm{H}_{2} \mathrm{SO}_{4}$. However, organic acid is known as an eco-friendly lixiviant, which is biodegradable and has non-toxic gas emissions [8,9]. Leaching of lithium cobalt oxide $\left(\mathrm{LiCoO}_{2}\right)$ is difficult due to the chemical bonds between cobalt and oxygen, which are extremely strong $[10,11]$. In the case of leaching with ascorbic acid $\left(\mathrm{C}_{6} \mathrm{H}_{8} \mathrm{O}_{6}\right)$, the waste $\mathrm{LiCoO}_{2}$ is dissolved and forms the soluble compound $\mathrm{C}_{6} \mathrm{H}_{6} \mathrm{O}_{6} \mathrm{Li}_{2}$, while $\mathrm{Co}(\mathrm{III})$ in $\mathrm{LiCoO}_{2}$ are further reduced to a soluble $\mathrm{Co}(\mathrm{II})$ by ascorbic acid. In the meantime, $\mathrm{C}_{6} \mathrm{H}_{8} \mathrm{O}_{6}$ is oxidized to dehydroascorbic acid $\left(\mathrm{C}_{6} \mathrm{H}_{6} \mathrm{O}_{6}\right)$ [12] . Subcritical water is one of the energy intensification processes; it is achieved by applying pressurized (10 to 60 bar) water in the temperature range of $100-374{ }^{\circ} \mathrm{C}$ that leads to enhanced mass transfer and accelerated chemical reaction [13]. Liu and Zhang [14] reported that more than 95\% of Co and Li were recovered from spent LIBs using polyvinyl chloride (PVC) in subcritical water extraction (SWE) under optimum condition of $350^{\circ} \mathrm{C}$ for $30 \mathrm{~min}$. A more recent study by Nshizirungu et al. [15] used waste chlorinated PVC (CPVC) as the source of $\mathrm{HCl}$ for $\mathrm{Li}$ and Co leaching from spent LIBs in a hydrothermal subcritical water process at $250{ }^{\circ} \mathrm{C}$ for $60 \mathrm{~min}$, and higher than $97 \%$, leaching efficiency of both metals was found. Although waste CPVC could be degraded, the process required high energy to decompose the PVC and then to release $\mathrm{Cl}^{-}$ions [16]. Therefore, the leaching of valuable metals ( $\mathrm{Li}, \mathrm{Co}$, and $\mathrm{Mn}$ ) from spent $\mathrm{LIBs}$ using $\mathrm{HCl}$ and ascorbic acid under lower temperatures $\left(100\right.$ to $\left.150{ }^{\circ} \mathrm{C}\right)$ by SWE was investigated in the current study.

To further assess the leaching mechanisms, the leaching residues of $\mathrm{HCl}$ and ascorbic acid were analyzed by X-ray photoelectron spectroscopy (XPS). This study aimed to examine the leaching of valuable metals from spent LIBs using an SWE process and to explore redox reactions at the spent LIBs' surfaces.

\section{Results}

\subsection{Effect of Acid Concentration}

The effect of acid concentration on SWE was studied using $0.05,0.1,0.2$, and $0.5 \mathrm{M}$ of leaching agent solutions at $100{ }^{\circ} \mathrm{C}$ for $30 \mathrm{~min}$, solid-to-liquid (S/L) ratio of $10 \mathrm{~g} / \mathrm{L}, 300 \mathrm{rpm}$ stirring speed, and initial pressure of 10 bar. Figure 1 shows that the concentration of the leaching agent had a significant effect on leaching efficiency of $\mathrm{Co}, \mathrm{Li}$, and $\mathrm{Mn}$. The leaching efficiency of $\mathrm{Co}, \mathrm{Li}$, and $\mathrm{Mn}$ increased from $7.06 \%$ to $29.49 \%, 27.14 \%$ to $68.01 \%$, and $31.69 \%$ to $49.23 \%$, respectively, as the concentration of $\mathrm{HCl}$ increased from $0.05 \mathrm{M}$ to $0.1 \mathrm{M}$, and further increased to $64.30 \%, 101.34 \%$, and $70.53 \%$ at $0.5 \mathrm{M}$ (Figure 1a). A similar trend was found when using ascorbic acid as shown in Figure 1b. The leaching efficiency increased from $34.59 \%$ to $96.17 \%$ for Co, from $58.99 \%$ to $97.54 \%$ for $\mathrm{Li}$, and from $46.04 \%$ to $99.24 \%$ for $\mathrm{Mn}$ by increasing the concentration of ascorbic acid from $0.05 \mathrm{M}$ to $0.2 \mathrm{M}$. The excess leaching efficiency $(>100 \%)$ as shown in some data may be due to non-uniform metal content in the spent LIBs. Ascorbic acid resulted in a higher leaching efficiency than $\mathrm{HCl}$ as a leaching agent for $\mathrm{Co}, \mathrm{Li}$, and $\mathrm{Mn}$ in spent LIBs, which may be attributed to its high reducibility. The deionization of ascorbic acid $\left(\mathrm{H}_{2} \mathrm{Asc}\right)$ is depending on the solution $\mathrm{pH}, \mathrm{H}_{2} \mathrm{Asc}$ will form ascorbate ion $\left(\mathrm{HAsc}^{-}\right)$and ascorbate dianion $\left(\mathrm{Asc}^{2-}\right)$ which is easily oxidized to dehydroascorbic acid (DAsc) [17]. The pKa values of ascorbic acid are $\mathrm{pKa}_{1}$ of 4.10 and $\mathrm{pKa}_{2}$ of 11.6 [12]. The $\mathrm{pH}$ of leaching solution revealed that the ascorbic acid existed in the solution as $\mathrm{HAsc}^{-}$at concentrations 0.05 to $0.2 \mathrm{M}(\mathrm{pH}>4.10)$, and as $\mathrm{H}_{2} \mathrm{Asc}$ at $0.5 \mathrm{M}(\mathrm{pH}<4.10)$. Table 1 shows that both $\mathrm{HCl}$ and ascorbic acid could be used as a reducing agent, however, the reduction potentials of $\mathrm{HAsc}^{-}$and $\mathrm{H}_{2} \mathrm{Asc}$ are much lower than that of $\mathrm{Cl}^{-}$, and $1.78 \mathrm{~V}$ and $1.73 \mathrm{~V}$ of overall potential was found in the reactions with $\mathrm{Co}(\mathrm{III})$, which is higher than $1.24 \mathrm{~V}_{\text {when }} \mathrm{Cl}^{-}$was involved. When ascorbic acid is oxidized, two electrons are released. Those electrons were used to reduce Co(III) in spent LIBs to Co(II), which is known to be more soluble in solution $[18,19]$. The addition of other reducing agents, such as hydrogen peroxide $\left(\mathrm{H}_{2} \mathrm{O}_{2}\right)$, sodium thiosulfate $\left(\mathrm{Na}_{2} \mathrm{~S}_{2} \mathrm{O}_{3}\right)$, and glucose $\left(\mathrm{C}_{6} \mathrm{H}_{12} \mathrm{O}_{6}\right)$ can enhance the dissolution of cobalt oxide $[20,21]$. The higher potential of overall reactions of ascorbic acid compounds $\left(\mathrm{H}_{2} \mathrm{Asc}\right.$ and $\left.\mathrm{HAsc}^{-}\right)$with cobalt (III) represent a higher driving force of the redox reaction. 
a)

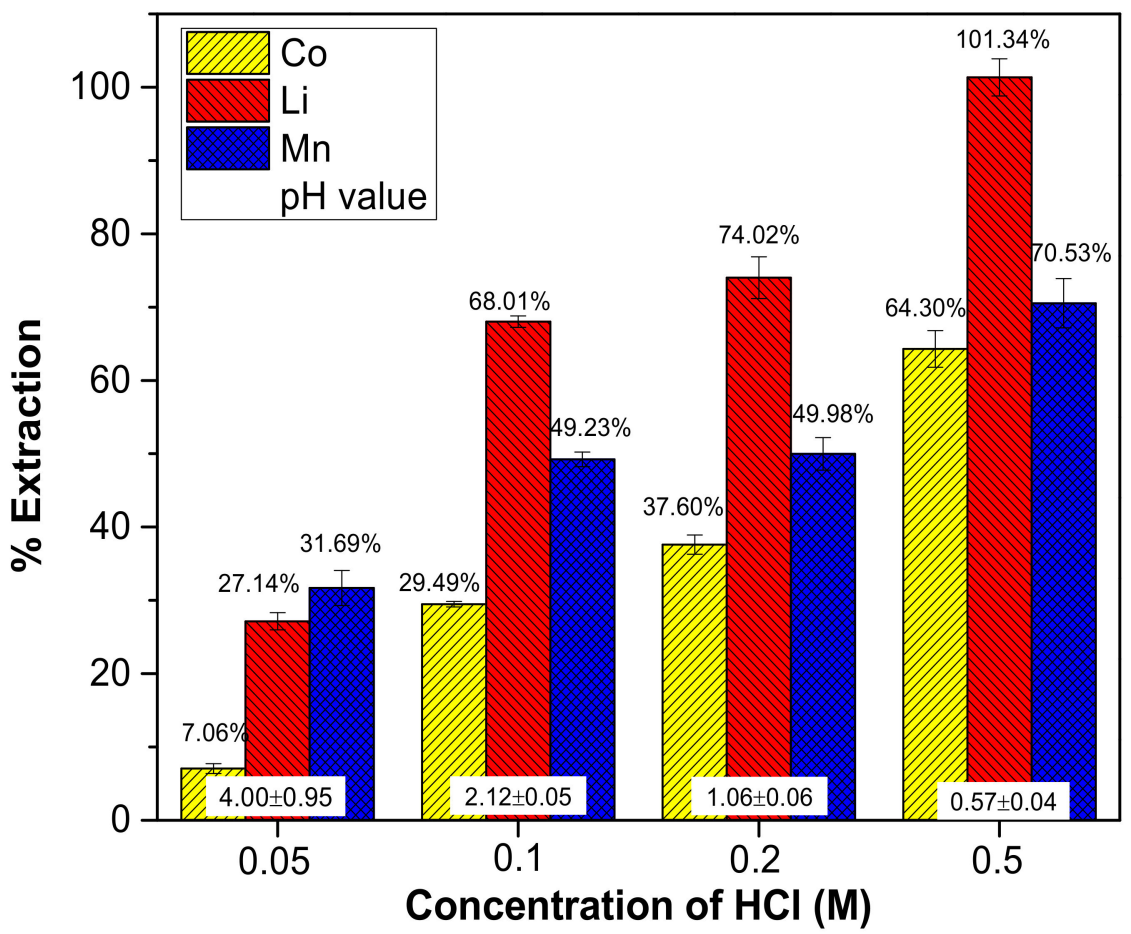

b)

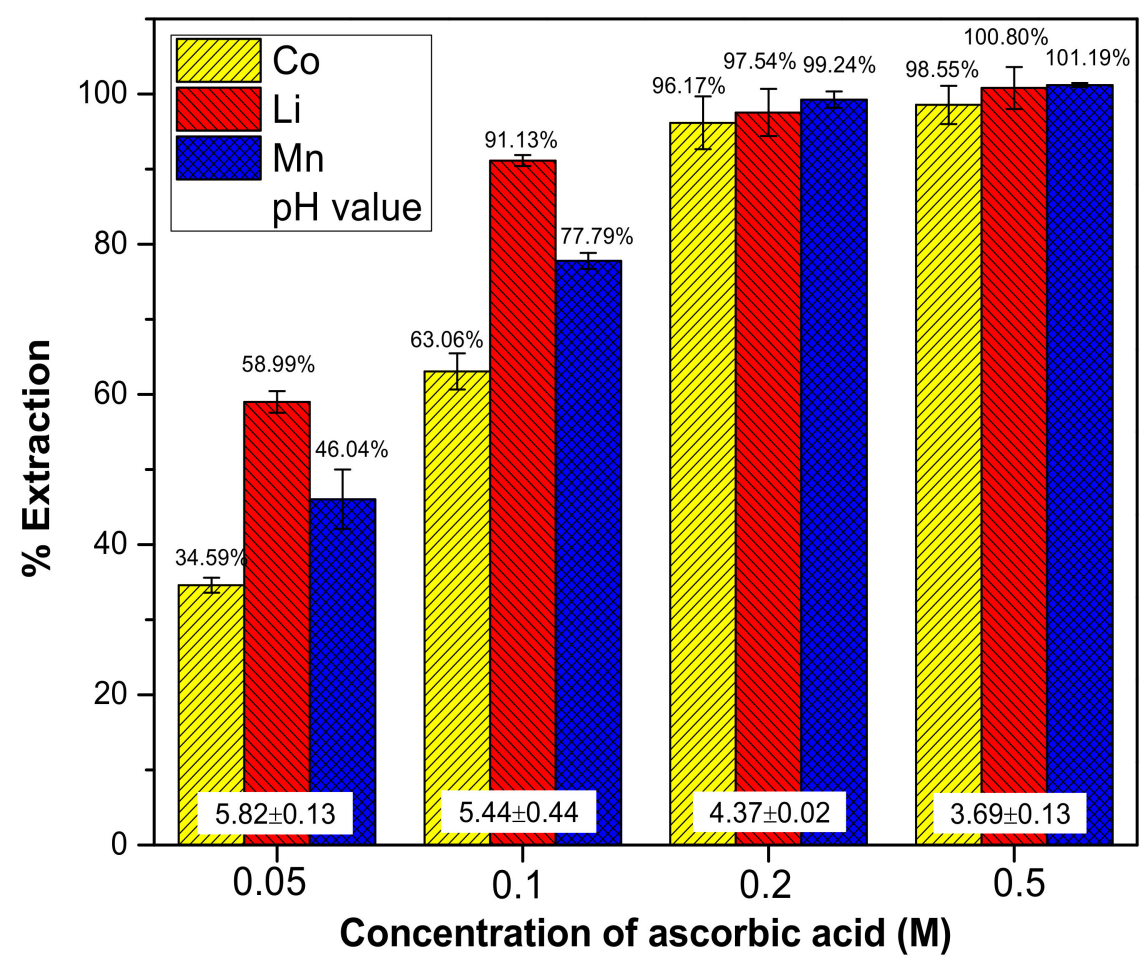

Figure 1. Effect of concentration on subcritical water extraction (SWE) at $100{ }^{\circ} \mathrm{C}, 10 \mathrm{bar}$, and solid-to-liquid (S/L) ratio of $10 \mathrm{~g} / \mathrm{L}$ for $30 \mathrm{~min}$ using (a) $\mathrm{HCl}$ and (b) ascorbic acid.

The stoichiometric concentrations of $\mathrm{HCl}$ and ascorbic acid to leach $\mathrm{Li}, \mathrm{Co}$, and $\mathrm{Mn}$ from $10 \mathrm{~g} / \mathrm{L}$ of spent LIBs were $0.4 \mathrm{M}$ and $0.2 \mathrm{M}$. However, when using $0.5 \mathrm{M}$ of $\mathrm{HCl}, \mathrm{S} / \mathrm{L}$ of $10 \mathrm{~g} / \mathrm{L}, 100{ }^{\circ} \mathrm{C}$ for 
$30 \mathrm{~min}$ resulted in leaching of only $64.30 \%$ of $\mathrm{Co}, 101.34 \%$ of $\mathrm{Li}$, and $70.53 \%$ of $\mathrm{Mn}$. On the other hand, higher than $95 \%$ leaching efficiency of $\mathrm{Co}, \mathrm{Li}$, and $\mathrm{Mn}$, respectively, was found when using $0.2 \mathrm{M}$ of ascorbic acid. These results confirmed that the $\mathrm{HCl}$ only provided acidity and limited the reducing capability to induce the leaching of $\mathrm{Co}, \mathrm{Li}$, and $\mathrm{Mn}$ in spent LIBs. While in the leaching process using ascorbic acid, $\mathrm{Li}$ was first dissolved by forming $\mathrm{C}_{6} \mathrm{H}_{6} \mathrm{O}_{6} \mathrm{Li}_{2}$, and $\mathrm{Co}(\mathrm{III}), \mathrm{Co}(\mathrm{IV})$, and $\mathrm{Mn}(\mathrm{IV})$ in spent LIBs were reduced to the more soluble $\mathrm{Co}(\mathrm{II})$ and $\mathrm{Mn}(\mathrm{II})$, while ascorbic acid $\left(\mathrm{C}_{6} \mathrm{H}_{8} \mathrm{O}_{6}\right)$ was oxidized to dehydroascorbic acid $\left(\mathrm{C}_{6} \mathrm{H}_{6} \mathrm{O}_{6}\right)$ [12]. The high temperature and pressure adopted in SWE enhanced solubility and mass transfer, and resulted in a more efficient leaching process with a lower concentration of leaching agent.

Table 1. Redox reaction of cobalt involved in spent lithium-ion batteries (LIBs) leaching.

\begin{tabular}{lllc}
\hline \multicolumn{1}{c}{ Leaching by $\mathbf{H C l}$} & \multicolumn{1}{c}{ Leaching by Ascorbic Acid } \\
\hline \multicolumn{1}{c}{ Reaction } & $\mathbf{E}^{\circ} / \mathbf{V}^{*}$ & \multicolumn{1}{c}{ Reaction } & $\mathbf{E}^{\circ} / \mathbf{V}^{*}$ \\
\hline $\mathrm{Co}^{3+}+\mathrm{e}^{-} \rightarrow \mathrm{Co}^{2+}$ & $1.92^{\mathrm{a}}$ & $\mathrm{Co}^{3+}+\mathrm{e}^{-} \rightarrow \mathrm{Co}^{2+}$ & $1.92^{\mathrm{a}}$ \\
$\mathrm{Cl}_{2(\mathrm{~g})}+2 \mathrm{e}^{-} \rightarrow 2 \mathrm{Cl}^{-}$ & $1.36^{\mathrm{a}}$ & $\mathrm{DAsc}+2 \mathrm{e}^{-}+\mathrm{H}^{+} \rightarrow \mathrm{HAsc}^{-}$ & $0.28^{\mathrm{b}}$ \\
& & $\mathrm{DAsc}+2 \mathrm{e}^{-}+2 \mathrm{H}^{+} \rightarrow \mathrm{H}_{2} \mathrm{Asc}$ & $0.39^{\mathrm{b}}$ \\
$2 \mathrm{Cl}^{-}+2 \mathrm{Co}^{3+} \rightarrow 2 \mathrm{Co}^{2+}+\mathrm{Cl}_{2(\mathrm{~g})}$ & \multirow{2}{*}{1.24} & $\mathrm{HAsc}^{-}+2 \mathrm{Co}^{3+} \rightarrow \mathrm{DAsc}+2 \mathrm{Co}^{2+}+\mathrm{H}^{+}$ & 1.78 \\
& & $\mathrm{H}_{2} \mathrm{Asc}+2 \mathrm{Co}^{3+} \rightarrow \mathrm{DAsc}+2 \mathrm{Co}^{2+}+2 \mathrm{H}^{+}$ & 1.73 \\
\hline
\end{tabular}

* selected standard electrode potentials in aqueous solutions at $25^{\circ} \mathrm{C}$ in $\mathrm{V}$ vs. NHE; ${ }^{\text {a }}$ referred to [22]; ${ }^{\mathrm{b}}$ referred to [23].

\subsection{Effect of Temperature}

The effect of temperature on SWE was studied using $0.1 \mathrm{M}$ of leaching agent, initial pressure of $10 \mathrm{bar}$, stirring speed of $300 \mathrm{rpm}$, solid-to-the liquid ratio of $10 \mathrm{~g} / \mathrm{L}$, for $30 \mathrm{~min}$. As shown in Figure $2 \mathrm{a}$, the leaching efficiency of $\mathrm{Co}, \mathrm{Li}$, and Mn slightly increased from $26.14 \%$ to $27.9 \%$, from $60.11 \%$ to $63.31 \%$, and from $48.85 \%$ to $54.73 \%$, respectively, when temperature increased from 100 to $125{ }^{\circ} \mathrm{C}$ using $\mathrm{HCl}$. At $150{ }^{\circ} \mathrm{C}$, the leaching efficiency of $\mathrm{Co}, \mathrm{Li}$, and $\mathrm{Mn}$ rose to $30.19 \%, 67.05 \%$, and $59.31 \%$, respectively. This might be attributed to more dissociation of water into hydroxonium ions $\left(\mathrm{H}_{3} \mathrm{O}^{+}\right)$under subcritical conditions at a higher temperature, which improved the hydrolysis of valuable metals in the leaching process [15]. Figure $2 \mathrm{~b}$ shows that leaching efficiency of $\mathrm{Co}, \mathrm{Li}$, and $\mathrm{Mn}$ decreased from $60.81 \%$ to $47.79 \%$, from $70.21 \%$ to $69.70 \%$, and from $76.45 \%$ to $75.03 \%$, respectively, by increasing temperature from 100 to $125^{\circ} \mathrm{C}$ when using ascorbic acid. The efficiency of Co, $\mathrm{Li}$, and Mn became even lower at $42.81 \%, 69.33 \%$, and $67.66 \%$, respectively, at $150{ }^{\circ} \mathrm{C}$. This was probably due to the decomposition of ascorbic acid in a hydrothermal condition. Subcritical water induces the decomposition of organic compounds into smaller fragments [14]. Karpushkin et al. [24] studied the hydrothermal transformations of $10 \%$ ascorbic acid at $160{ }^{\circ} \mathrm{C}$ for 2 to $24 \mathrm{~h}$ and the results indicated that the decomposition of ascorbic acid was accompanied by decarboxylation to form insoluble compounds and other gaseous products. Another investigation by Mogol and Gökmen [25] reported the degradation rate of ascorbic acid to intermediate products by hydrolysis was higher than that of ascorbic acid oxidation to dehydroascorbic acid as heating temperature increased to $140^{\circ} \mathrm{C}$. It is noted that even though effective leaching for $\mathrm{Co}, \mathrm{Li}$, and $\mathrm{Mn}$ from spent LIBs by SWE is possible using low concentrations of ascorbic acid, the temperature should be kept as low as possible. On the contrary, higher acid concentration and temperature are necessary when using $\mathrm{HCl}$. However, ascorbic acid is more expensive than $\mathrm{HCl}$, therefore a cost-effectiveness analysis is required in selecting the optimum conditions for the recycling process of spent LIBs. 
a)

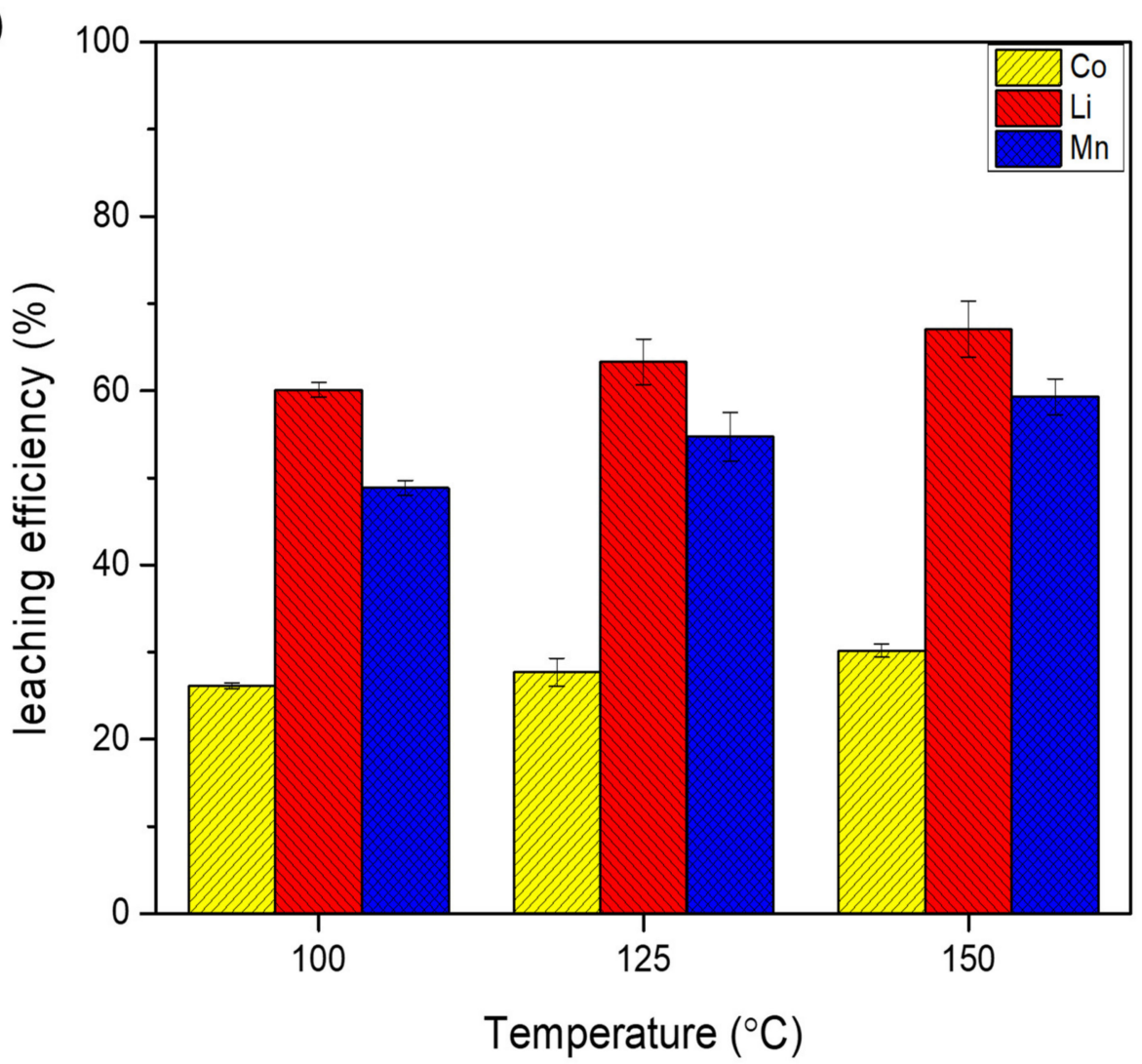

b)

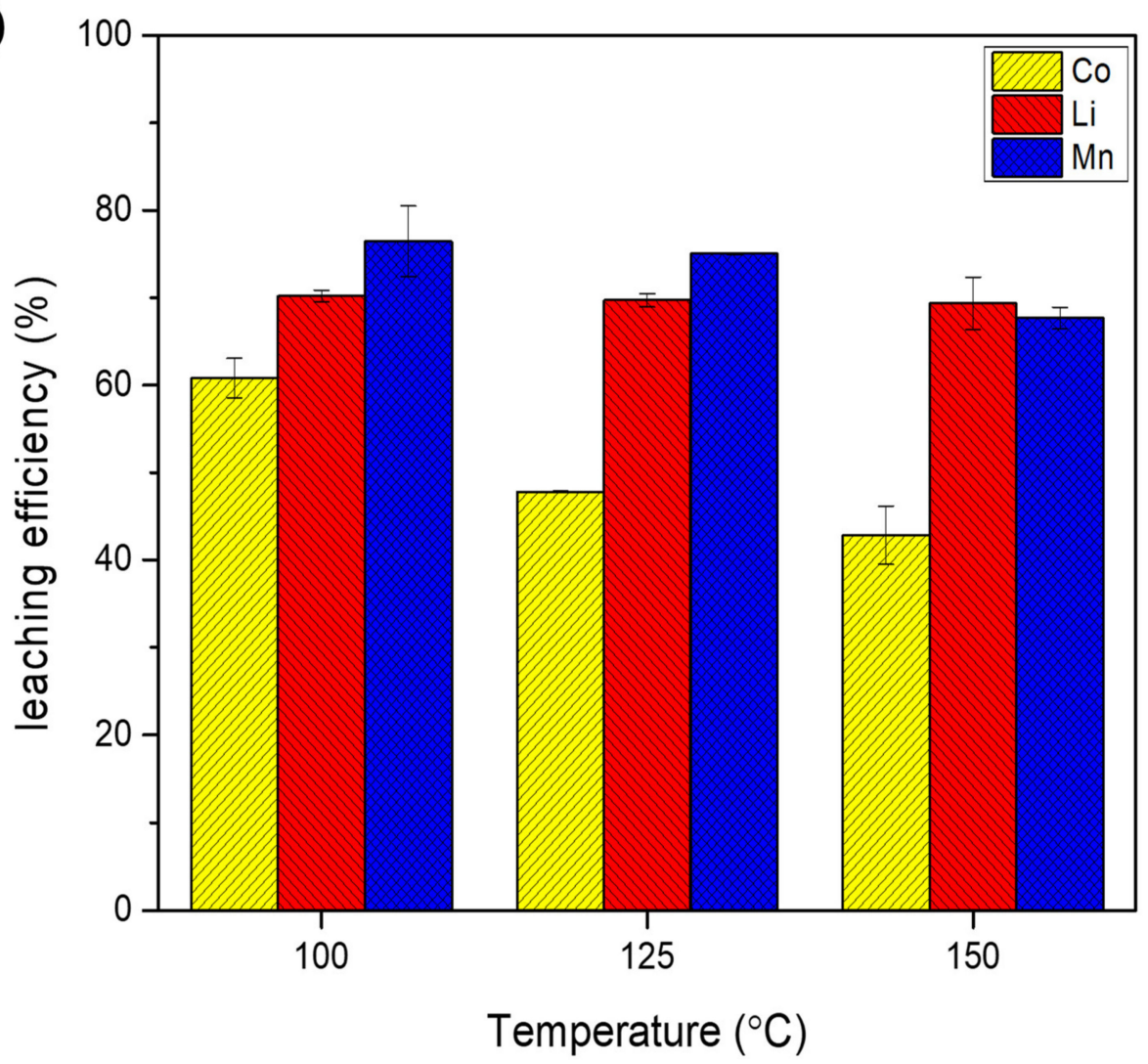

Figure 2. Effect of temperature on SWE at $\mathrm{S} / \mathrm{L}$ of $10 \mathrm{~g} / \mathrm{L}$ for $30 \mathrm{~min}$ using $0.1 \mathrm{M}$ of (a) $\mathrm{HCl}$ and (b) ascorbic acid. 


\subsection{Dissolution of Cobalt from Spent LIBS}

As mentioned in the previous section, Co leaching is enhanced as Co(III) is reduced to a more soluble Co(II) compound. However, most published papers have only postulated that some reducing agents could be induce the reaction by standard redox potential [17-20]. To examine redox reactions occurring during SWE leaching at the spent LIBs' surfaces, X-ray photoelectron spectroscopy (XPS) was used to assess the chemical composition of the solid before and after leaching in $0.5 \mathrm{M}$ of $\mathrm{HCl}$ and $0.5 \mathrm{M}$ of ascorbic acid using SWE at $100^{\circ} \mathrm{C}$ for $30 \mathrm{~min}$. The wide scan of the sample in Figure 3a shows the decreasing intensity of the XPS spectra of spent LIBs after being subjected to the leaching process using $\mathrm{HCl}$ and ascorbic acid (AA) due to the dissolution of the compounds. The highest peaks in XPS spectra of spent LIBs' powder included C1s as carbon or graphite content of the anode powder in LIBs, O1s as oxygen content from the oxide compounds in LIBs, and F1s as the fluoride content in LIBs' binders, mostly polyvinylidene fluoride (PVDF). Figure $3 \mathrm{~b}$ shows that XPS spectra of the Co $2 \mathrm{p}$ peak of spent LIBs consisted of Co $2 p_{3 / 2}$, Co $2 p_{3 / 2}$ satellites, and Co $2 p_{1 / 2}$. The corresponding binding energy (BE) and the compositions are illustrated in Table 2. The presence of $\mathrm{Co}$ in the $\mathrm{LIBs}^{\prime}$ cathode $\left(\mathrm{LiCoO}_{2}\right)$ is predominantly in the form of $\mathrm{Co}(\mathrm{III})$. It is transformed into the inactive compounds (mostly $\mathrm{Co}_{3} \mathrm{O}_{4}$, followed by $\mathrm{Co}_{2} \mathrm{O}_{3}$ and $\mathrm{CoO}$ ) in spent LIBs due to the reactions during migration of $\mathrm{Co}$ ions and due to the detrimental effect of the binder [26]. The ratio of $\mathrm{Co}$ (II) to $\mathrm{Co}$ (III) in spent LIBs was 1.141, implying that the concentration of $\mathrm{Co}$ (II) oxide was higher than $\mathrm{Co}(\mathrm{III})$ oxide. The satellite peaks of $\mathrm{Co} 2 \mathrm{p}_{3 / 2}$ were represented at $785 \mathrm{eV}$ and $789.8 \mathrm{eV}$, corresponding to $\mathrm{Co}(\mathrm{II})$ and $\mathrm{Co}(\mathrm{III})$ excitation [27].

The peak area of $\mathrm{Co}$ (II) in the leaching residue using $\mathrm{HCl}$ became much smaller and the ratio of $\mathrm{Co}(\mathrm{II})$ to $\mathrm{Co}(\mathrm{III})$ decreased to 0.550 . This confirmed that most of the Co(II) oxide in spent LIBs was dissolved in $\mathrm{HCl}$ but not for $\mathrm{Co}(\mathrm{III})$ oxide. The XPS results of cobalt demonstrated that dissolution of the $\mathrm{Co}(\mathrm{II})$ compound is more significant in acid solution than that of $\mathrm{Co}(\mathrm{III})$. A significant amount of $\mathrm{Co}$ (III) was still found in the leaching residue using $0.5 \mathrm{M} \mathrm{HCl}$, while no Co $2 \mathrm{p}$ peak could be detected when using ascorbic acid. This was due to the complete dissolution of Co content in spent LIBs in the leaching process. These results were in agreement with the aforementioned redox potential prediction that ascorbic acid had a higher driving force than $\mathrm{HCl}$ to reduce $\mathrm{Co}(\mathrm{III})$ to $\mathrm{Co}(\mathrm{II})$.

The XRD spectra of leaching residue of $\mathrm{HCl}$ and ascorbic acid (Figure S7) showed that the leaching residue of $\mathrm{HCl}$ still contained $\mathrm{LiCoO}_{2}, \mathrm{Li}_{2} \mathrm{CoMn}_{3} \mathrm{O}_{8}$, and $\mathrm{Co}_{3} \mathrm{O}_{4}$, while the leaching residue of ascorbic acid mostly contained carbon of the anode powder, elemental $\mathrm{Cu}$ (COD 9011604) from the reduction $\mathrm{Cu}(\mathrm{II})$ by ascorbic acid [28,29], and the insoluble product of ascorbic acid hydrolysis, D-isoascorbic acid (PDF 32-1637).

Table 2. XPS analysis of surface compositions of spent LIBs' powder and leaching residue.

\begin{tabular}{cccccccc}
\hline \multirow{2}{*}{ Peak } & \multicolumn{2}{c}{ Spent LIBs } & \multicolumn{2}{c}{ Leaching Residue HCl } & \multicolumn{2}{c}{ Leaching Residue AA } & \multirow{2}{*}{ Assignment } \\
\cline { 2 - 6 } & BE (eV) & Ratio & BE (eV) & Ratio & BE (eV) & Ratio & \\
\hline Co & 780.28 & 1.000 & 780.32 & 1.000 & n.d. & n.d. & \multirow{2}{*}{ Co 2 $\mathrm{p}_{3 / 2}:$ Co(III) } \\
$2 \mathrm{p}$ & 782.36 & 1.141 & 781.82 & 0.550 & n.d. & n.d. & Co 2 $\mathrm{p}_{3 / 2}:$ Co (II) \\
\hline
\end{tabular}


a)

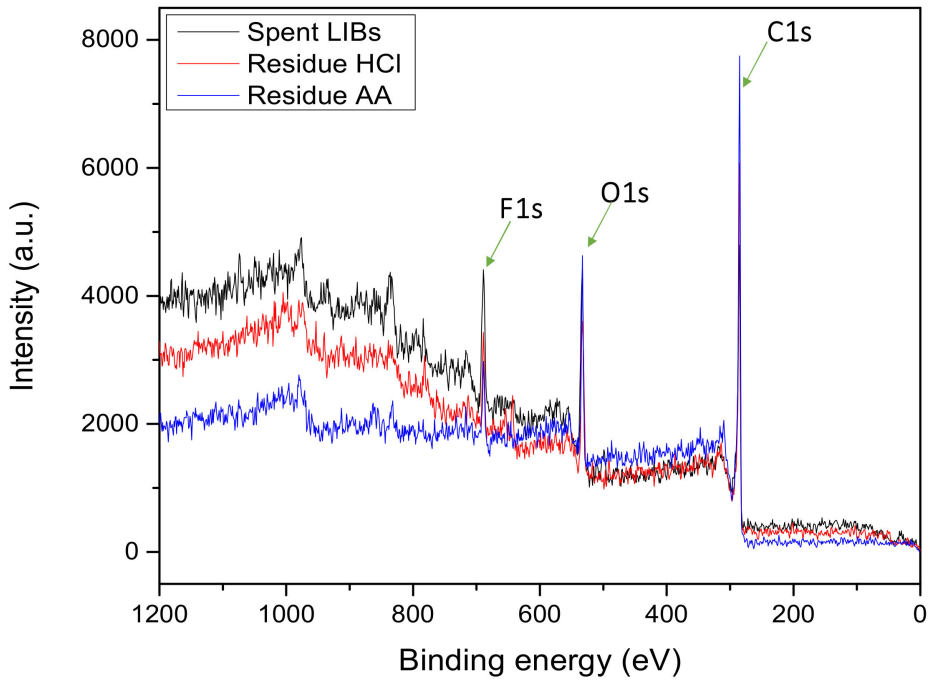

b)

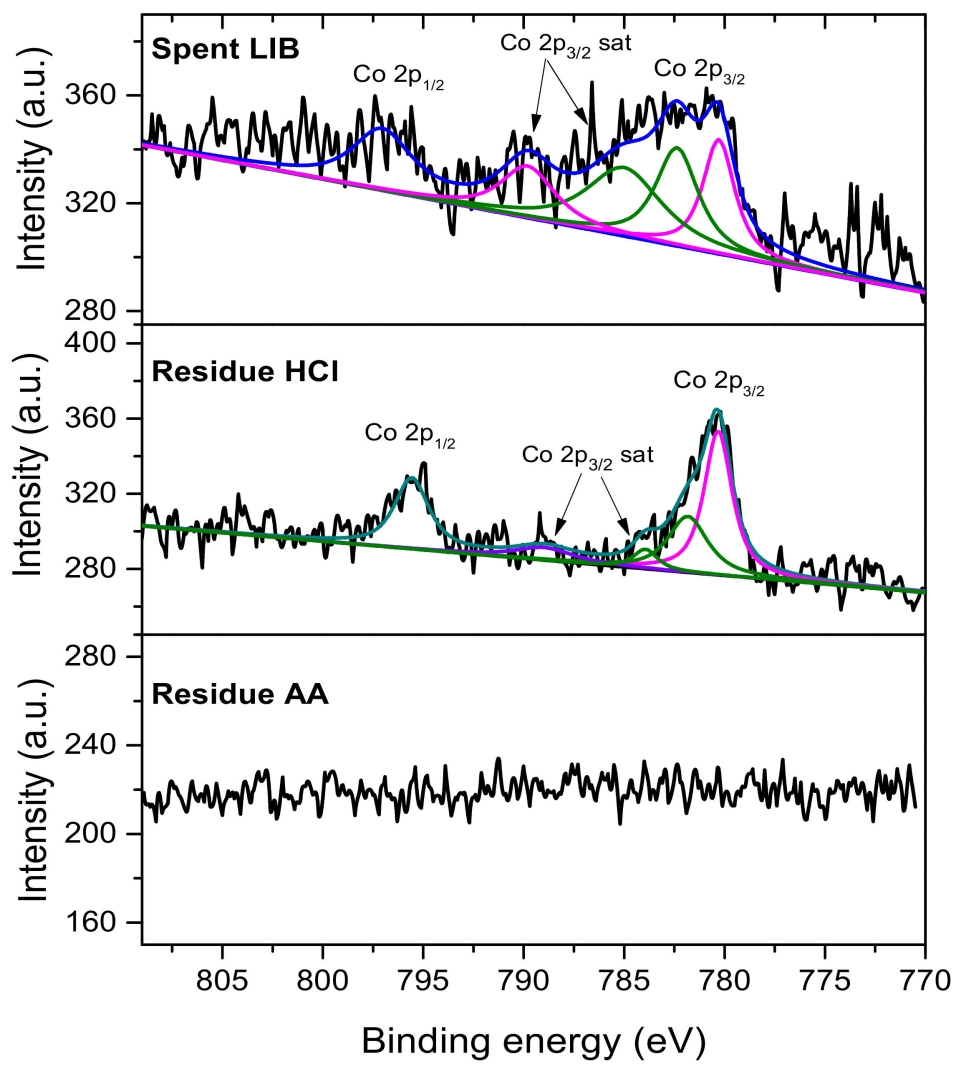

Figure 3. XPS result of spent LIBs and leaching residue using $\mathrm{HCl}$ and ascorbic acid (AA) in SWE (a) wide scan and (b) Co 2p peak.

\subsection{Conventional Leaching}

The experiments using a conventional leaching method were carried out using $\mathrm{HCl}$ and ascorbic acid at three different temperatures $\left(25,45\right.$, and $\left.65^{\circ} \mathrm{C}\right)$, different reaction times $(1,2,4,6,8,10,20,30,60$, $90,120,180,240,360,480,600$, and $720 \mathrm{~min}$ ), acid concentration of $0.5 \mathrm{M}$, and $\mathrm{S} / \mathrm{L}$ of $10 \mathrm{~g} / \mathrm{L}$. The leaching efficiency of $\mathrm{Co}, \mathrm{Li}$, and $\mathrm{Mn}$ from cathode powder of spent LIBs at various temperatures are shown in Figures S1-S6. Lower leaching efficiency of $\mathrm{Co}, \mathrm{Li}$, and $\mathrm{Mn}$ was found compared with those of SWE. 
The leaching efficiency of $\mathrm{Co}$, $\mathrm{Li}$, and $\mathrm{Mn}$ using $\mathrm{HCl}$ at $65{ }^{\circ} \mathrm{C}$ for $4 \mathrm{~h}$ were $42.19 \%, 80.46 \%$, and $54.13 \%$, respectively, as compared with $96.36 \%$ of $\mathrm{Co}, 95.54 \%$ of $\mathrm{Li}$, and $97.9 \%$ of $\mathrm{Mn}$ using ascorbic acid at $65^{\circ} \mathrm{C}$ for $4 \mathrm{~h}$ min. In general, the conventional extraction required a much longer time to achieve comparable leaching efficiency of $\mathrm{Li}, \mathrm{Co}$, and $\mathrm{Mn}$ when compared with SWE. The activation energy of $\mathrm{Co}, \mathrm{Li}$, and Mn was determined by using the Arrhenius equation from conventional leaching kinetic study (Tables S1-S6), which fitted well with a pseudo-second-order kinetic model. Table S7 shows that the activation energy of $\mathrm{Co}, \mathrm{Li}$, and $\mathrm{Mn}$ in $\mathrm{HCl}$ are higher than in ascorbic acid. In addition, the activation energy of a diffusion-controlled process is usually below $40 \mathrm{~kJ} / \mathrm{mol}$, while for a chemically controlled reaction, the value is usually greater than $40 \mathrm{~kJ} / \mathrm{mol}[29,30]$. Therefore, both diffusion and chemical reaction processes were involved in the leaching of $\mathrm{Co}, \mathrm{Li}$, and $\mathrm{Mn}$ from spent $\mathrm{LIBs}$ using $\mathrm{HCl}$ and ascorbic acid.

\section{Material and Methods}

The spent LIBs' powder was obtained from Yen-Long Renewable Technology Co., Ltd. (Kaohsiung, Taiwan). It was pretreated by sieving through 140 mesh to retain particle sizes less than $105 \mu \mathrm{m}$. The surface morphology of the cathode powder of spent LIBs was examined by field-emission scanning electron microscope with an energy dispersive spectrometer (FESEM-EDS, JSM-6500F, JEOL, Tokyo, Japan) as shown in Figure 4a. The spent LIBs' powder had irregular shapes, and had sizes ranging from 10 to $100 \mu \mathrm{m}$. The elemental composition based on the EDS results can be seen in Figure $4 \mathrm{~b}$, which confirmed that spent LIBs contained C from the anode powder, and Co and Mn from the cathode powder. However, Li could not be detected in EDS analysis due to its low atomic number and weight. The X-ray photoelectron spectroscopy (XPS, Thermo Fischer Scientific, VG ESCALAB 250, Waltham, MA, U.S.) analysis was conducted to assess the chemical composition of spent LIBs and the leaching residue. The XPS analysis was carried out with microfocused monochromatized $\mathrm{Al} \mathrm{K} \alpha$ radiation $\mathrm{hv}=1200 \mathrm{eV}$, X-ray gun at $15 \mathrm{kV}$ and $200 \mathrm{~W}$, and beam size 650-120 $\mu \mathrm{m}$. The binding energy scale was calibrated from the carbon contamination using $\mathrm{C} 1 \mathrm{~s}$ peak at $284.5 \mathrm{eV}$. The aqua regia digestion method (NIEA S321.63B, Taipei, Taiwan) was used to dissolve all of the metals in the spent LIBs' powder, the solution was then analyzed in inductively coupled plasma-atomic emission spectrometry (ICP-AES, JY-2000, Horiba, Tokyo, Japan) for total metal content. X-ray powder diffraction (XRD, D2 PHASER, Bruker, Karlsruhe, Germany) was also used to characterize the spent LIBs' powder (Figure 5). It revealed that spent LIBs' powder was the mixture of the anode, which is mostly graphite (C with COD 9000046), and several kinds of compounds used as the cathode, including lithium cobalt oxide $\left(\mathrm{LiCoO}_{2}\right.$ with PDF 44-0145), lithium cobalt-manganese oxide $\left(\mathrm{Li}_{2} \mathrm{CoMn}_{3} \mathrm{O}_{8}\right.$ with PDF 48-0261), cobalt oxide $\left(\mathrm{Co}_{3} \mathrm{O}_{4}\right.$ with COD 5910031), and lithium iron phosphate $\left(\mathrm{LiFePO}_{4}\right.$ with COD 1011090). The characteristics of leaching residue of aqua regia digestion can be found in Figure 5. The XRD analysis demonstrated that all of the metal hydroxide compounds of the sample were leached out completely.

The SWE of Co, Li, and Mn from spent LIBs were conducted in a $200 \mathrm{~mL}$ cylindrical stainless-steel batch reactor (temperature limit: $100-300{ }^{\circ} \mathrm{C}$, pressure range: $0-100$ bar) equipped with a magnetic stirrer, thermocouple connected to the electric heater as well as the temperature controller, pressure gauge, and nitrogen gas tube [13]. A solution at $10 \mathrm{~g} / \mathrm{L}$ of spent LIBs' powder to leaching agent was placed into the SWE glass chamber and put into the SWE reactor. The reactor was closed and sealed with its cap using M8 screws. The initial pressure was set 10 bar by adding $\mathrm{N}_{2}$ gas into the SWE reactor to maintain the leaching process in the liquid phase. It was stirred at $300 \mathrm{rpm}$ and heated to the desired temperature $\left(100,125\right.$, or $\left.150{ }^{\circ} \mathrm{C}\right)$ and kept there for $30 \mathrm{~min}$ of leaching time. After cooling to room temperature, the leaching mixture was filtered. The metal content in the leaching solution was analyzed using ICP-AES while the leaching residue was dried at $50{ }^{\circ} \mathrm{C}$ in a drying oven for 3 days and characterized. The experiments were carried out in triplicate and the average value was recorded. Equation (1) was used to calculate the leaching efficiency of each metal, in which $C_{s}$ is the concentration of metal in the leaching solution and $\mathrm{C}_{\mathrm{t}}$ is the total concentration of metal in spent LIBs' powder as determined by aqua regia digestion shown in Table 3. Cobalt has the highest concentration in the cathode powder (51.34\%), followed by $\mathrm{Mn}(28.12 \%), \mathrm{Li}(7.69 \%)$, and other elements including 
$\mathrm{Ni}, \mathrm{Al}, \mathrm{Fe}$, and $\mathrm{Cu}$. These results were in agreement with the literature that $\mathrm{Co}$ is the most abundant component in LIBs [31].

$$
\% \text { extraction }=\frac{C_{s}}{C_{t}} \times 100 \%
$$

a)

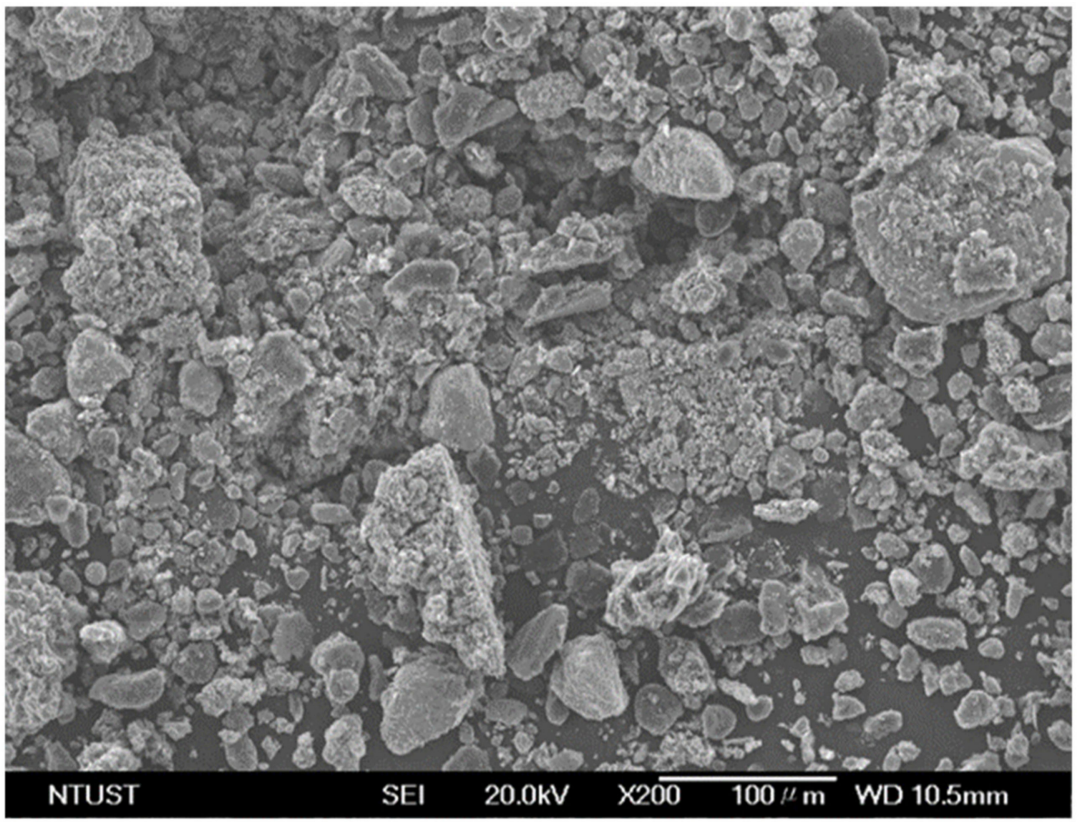

b)

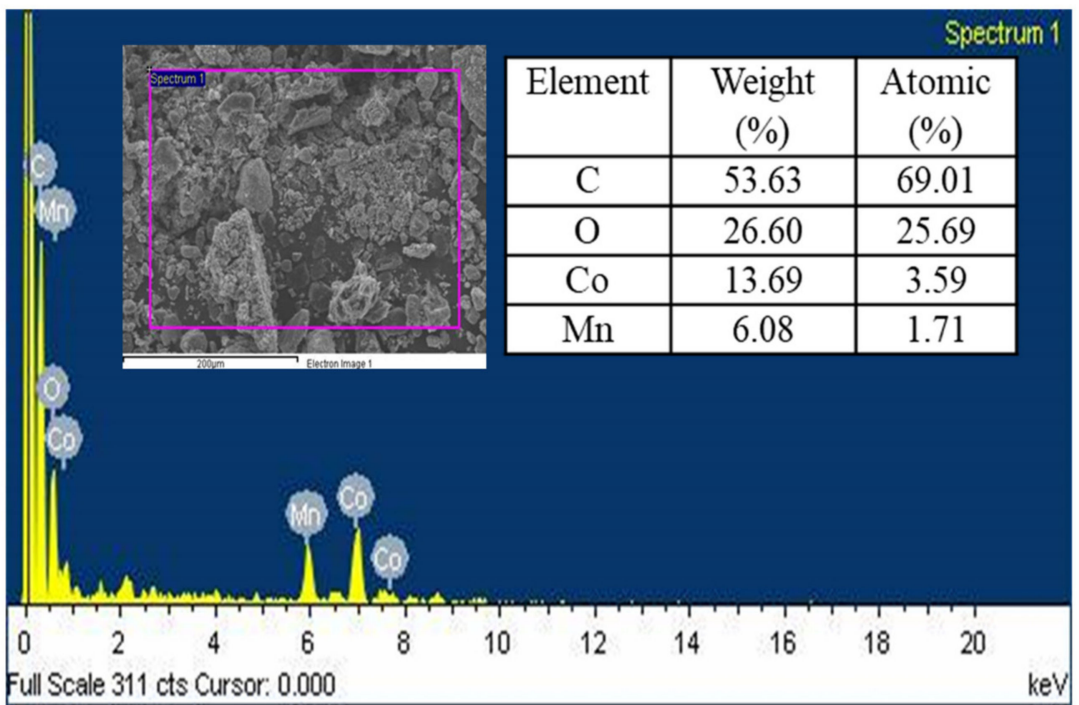

Figure 4. (a) FESEM image and (b) EDS result of cathode powder of spent LIBs. 


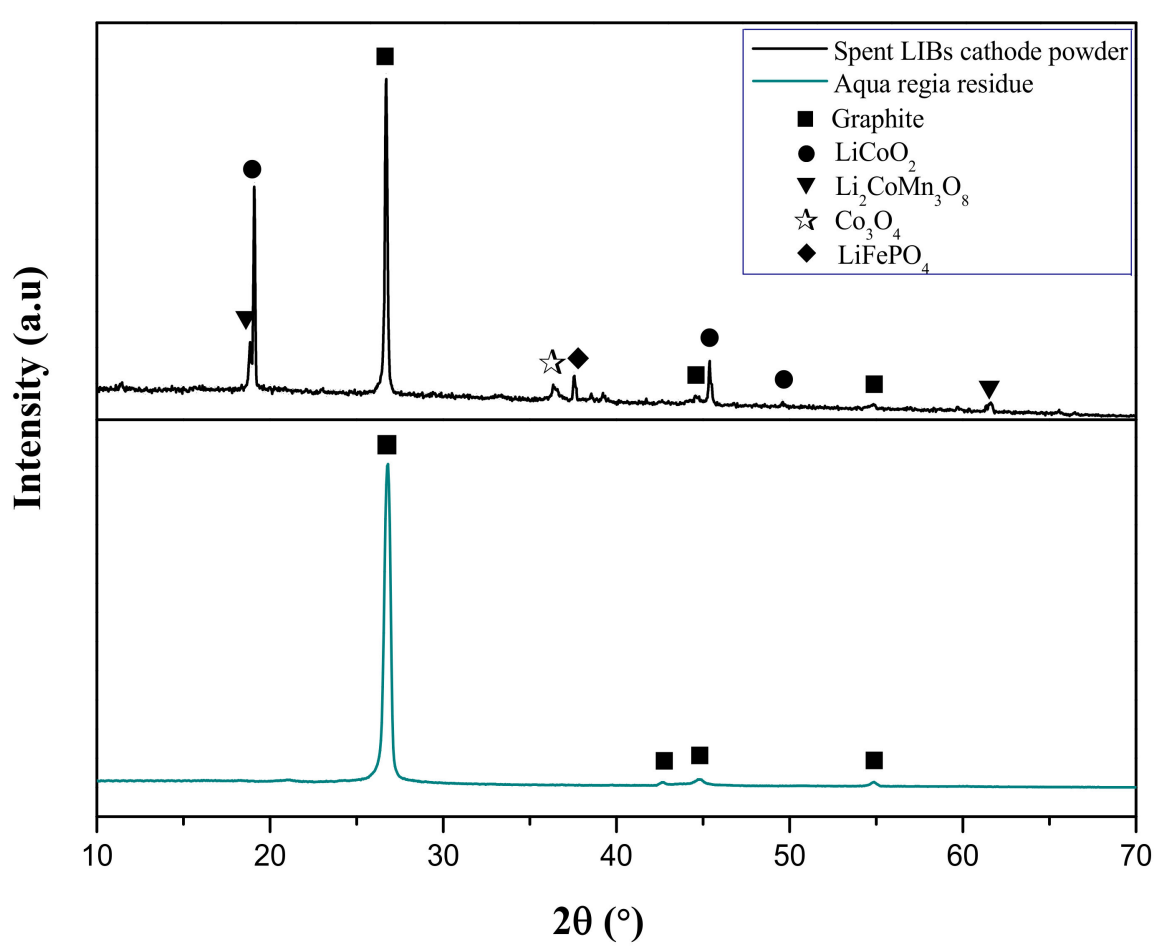

Figure 5. XRD spectra of spent LIBs' cathode powder and residue of aqua regia digestion.

Table 3. Metal compositions of cathode powder from spent LIBs.

\begin{tabular}{ccc}
\hline Component & Content $(\mathbf{m g} / \mathbf{g})$ & Mass Fraction $(\%){ }^{*}$ \\
\hline $\mathrm{Co}$ & $188.93 \pm 3.01$ & 51.34 \\
$\mathrm{Mn}$ & $103.46 \pm 2.09$ & 28.12 \\
$\mathrm{Li}$ & $28.31 \pm 0.36$ & 7.69 \\
$\mathrm{Ni}$ & $17.79 \pm 0.11$ & 4.83 \\
$\mathrm{Al}$ & $12.07 \pm 0.07$ & 3.28 \\
$\mathrm{Fe}$ & $9.27 \pm 0.25$ & 2.52 \\
$\mathrm{Cu}$ & $8.14 \pm 0.06$ & 2.21 \\
\hline \multicolumn{3}{c}{}
\end{tabular}

\section{Conclusions}

The leaching of valuable metals from spent LIBs' cathode powder using SWE was investigated, and the results showed that SWE was more effective and efficient in leaching of $\mathrm{Co}, \mathrm{Li}$, and $\mathrm{Mn}$ than the conventional method. The acid concentration played a key role in the leaching efficiency of spent LIBs using SWE. Ascorbic acid yielded better leaching efficiency than $\mathrm{HCl}$, since it can act as an acidic leaching agent and a stronger reducing agent, while $\mathrm{HCl}$ performed mainly as an acidic leaching agent. The redox reactions at the LIBs' cathode powder surfaces were examined by XPS, which provided solid evidence of the reduction of $\mathrm{Co}$ (III) to $\mathrm{Co}$ (II) by $\mathrm{HCl}$ to a limited extent, and a complete reaction by ascorbic acid. Higher temperatures of SWE using $\mathrm{HCl}$ resulted in higher leaching efficiency of valuable metals. However, temperatures $>100{ }^{\circ} \mathrm{C}$ of SWE using ascorbic acid resulted in lower efficiency owing to decomposition reactions of ascorbic acid under subcritical conditions. Complete leaching of $\mathrm{Co}$, $\mathrm{Li}$, and $\mathrm{Mn}$ from cathode powder of spent LIBs were obtained by SWE using $0.5 \mathrm{M}$ of ascorbic acid at $100{ }^{\circ} \mathrm{C}$ with $10 \mathrm{~g} / \mathrm{L}$ solid/liquid ratio, within $30 \mathrm{~min}$. In summary, the SWE process showed the advantages of higher efficiency, shorter reaction time, and lower acid concentrations required. It has very good potential as an alternative process for spent LIBs recycling. 
Supplementary Materials: The following are available online. Figure S1: Kinetic plot of Co extraction at different temperature using $0.5 \mathrm{M} \mathrm{HCl}$ with $10 \mathrm{~g} / \mathrm{L}$ of solid to liquid ratio, Figure S2: Kinetic plot of Li extraction at different temperatures using $0.5 \mathrm{M} \mathrm{HCl}$ with $10 \mathrm{~g} / \mathrm{L}$ of solid to liquid ratio, Figure S3: Kinetic plot of Mn extraction at different temperature using $0.5 \mathrm{M} \mathrm{HCl}$ with $10 \mathrm{~g} / \mathrm{L}$ of solid to liquid ratio, Figure S4: Kinetic plot of Co extraction at different temperatures using $0.5 \mathrm{M}$ ascorbic acid with $10 \mathrm{~g} / \mathrm{L}$ of solid to liquid ratio, Figure S5: Kinetic plot of Li extraction at different temperatures using $0.5 \mathrm{M}$ ascorbic acid with $10 \mathrm{~g} / \mathrm{L}$ of solid to liquid ratio, Figure S6: Kinetic plot of Mn extraction at different temperatures using $0.5 \mathrm{M}$ ascorbic acid with $10 \mathrm{~g} / \mathrm{L}$ of solid to liquid ratio, Figure S7: XRD spectra of leaching residues of ascorbic acid and $\mathrm{HCl}$ after subject to SWE, Table S1: Kinetic parameters of Co extraction with $0.5 \mathrm{M} \mathrm{HCl}$, Table S2: Kinetic parameters of Li extraction with $0.5 \mathrm{M} \mathrm{HCl}$, Table S3: Kinetic parameters of Mn extraction with $0.5 \mathrm{M} \mathrm{HCl}$, Table S4: Kinetic parameters of Co extraction with $0.5 \mathrm{M}$ ascorbic acid, Table S5: Kinetic parameters of Li extraction with $0.5 \mathrm{M}$ ascorbic acid, Table S6: Kinetic parameters of Mn extraction with $0.5 \mathrm{M}$ ascorbic acid, Table S7: Activation energy using Arrhenius equation for leaching $\mathrm{Co}, \mathrm{Li}$, and $\mathrm{Mn}$ from spent lithium ion batteries in $0.5 \mathrm{M}$ of $\mathrm{HCl}$ and ascorbic acid.

Author Contributions: S.T. and J.-C.L. developed the research concept and design. J.-C.L. facilitated the experiment. S.T. performed the spent LIBs' characterization and the extraction of valuable metals from spent LIBs using conventional and SWE methods. J.L. examined the effect of temperature, XPS, and XRD analysis of spent LIBs and leaching residue, and wrote the manuscript. J.C.L. assisted with data analysis and interpretation, and revised the manuscript. All authors have read and agreed to the published version of the manuscript.

Funding: This research received no external funding.

Acknowledgments: The authors are grateful to Mr. Feng-Mou Ho, the plant manager of Yen-Long Renewable Technology Co., Ltd., for providing LIBs samples and valuable information, and for the advice from Yu-Lin Kuo of the Department of Mechanical Engineering, National Taiwan University of Science and Technology on the interpretation of the results from XPS.

Conflicts of Interest: The authors declare no conflict of interest.

\section{References}

1. Harper, G.; Sommerville, R.; Kendrick, E.; Driscoll, L.; Slater, P.; Stolkin, R.; Walton, A.; Christensen, P.; Heidrich, O.; Lambert, S.; et al. Recycling lithium-ion batteries from electric vehicles. Nature 2019, 575, 75-86. [CrossRef]

2. He, L.P.; Sun, S.Y.; Song, X.F.; Yu, J.G. Leaching process for recovering valuable metals from the LiNi1/3Co1/3Mn1/3O2cathode of lithium-ion batteries. Waste Manag. 2017, 64, 171-181. [CrossRef]

3. Yao, Y.; Zhu, M.; Zhao, Z.; Tong, B.; Fan, Y.; Hua, Z. Hydrometallurgical processes for recycling spent lithium-Ion batteries: A critical review. ACS Sustain. Chem. Eng. 2018, 6, 13611-13627. [CrossRef]

4. Liu, C.; Lin, J.; Cao, H.; Zhang, Y.; Sun, Z. Recycling of spent lithium-ion batteries in view of lithium recovery: A critical review. J. Clean. Prod. 2019, 228, 801-813. [CrossRef]

5. Gao, W.; Song, J.; Cao, H.; Lin, X.; Zhang, X.; Zheng, X.; Zhang, Y.; Sun, Z. Selective recovery of valuable metals from spent lithium-ion batteries-Process development and kinetics evaluation. J. Clean. Prod. 2018, 178, 833-845. [CrossRef]

6. Barik, S.P.; Prabaharan, G.; Kumar, B. An innovative approach to recover the metal values from spent lithium-ion batteries. Waste Manag. 2016, 51, 222-226. [CrossRef]

7. Lv, W.; Wang, Z.; Cao, H.; Sun, Y.; Zhang, Y.; Sun, Z. A critical review and analysis on the recycling of spent lithium-ion batteries. ACS Sustain. Chem. Eng. 2018, 6, 1504-1521. [CrossRef]

8. Golmohammadzadeh, R.; Rashchi, F.; Vahidi, E. Recovery of lithium and cobalt from spent lithium-ion batteries using organic acids: Process optimization and kinetic aspects. Waste Manag. 2017, 64, $244-254$. [CrossRef] [PubMed]

9. Meshram, P.; Mishra, A.; Sahu, R. Environmental impact of spent lithium ion batteries and green recycling perspectives by organic acids-A review. Chemosphere 2020, 242, 125291. [CrossRef] [PubMed]

10. Jha, M.K.; Lee, J.C.; Kim, M.S.; Jeong, J.; Kim, B.S.; Kumar, V. Hydrometallurgical recovery/recycling of platinum by the leaching of spent catalysts: A review. Hydrometallurgy 2013, 133, 23-32. [CrossRef]

11. Zeng, X.; Li, J.; Singh, N. Recycling of spent lithium-ion battery: A critical review. Crit. Rev. Environ. Sci. Technol. 2014, 44, 1129-1165. [CrossRef]

12. Li, L.; Lu, J.; Ren, Y.; Zhang, X.X.; Chen, R.J.; Wu, F.; Amine, K. Ascorbic-acid-assisted recovery of cobalt and lithium from spent Li-ion batteries. J. Power Sources 2012, 218, 21-27. [CrossRef]

13. Lin, E.Y.; Rahmawati, A.; Ko, J.H.; Liu, J.C. Extraction of yttrium and europium from waste cathode-ray tube (CRT) phosphor by subcritical water. Sep. Purif. Technol. 2018, 192, 166-175. [CrossRef] 
14. Liu, K.; Zhang, F.S. Innovative leaching of cobalt and lithium from spent lithium-ion batteries and simultaneous dechlorination of polyvinyl chloride in subcritical water. J. Hazard. Mater. 2016, 316, 19-25. [CrossRef] [PubMed]

15. Nshizirungu, T.; Agarwal, A.; Jo, Y.T.; Rana, M.; Shin, D.; Park, J.H. Chlorinated polyvinyl chloride (CPVC) assisted leaching of lithium and cobalt from spent lithium-ion battery in subcritical water. J. Hazard. Mater. 2020, 393, 122367. [CrossRef] [PubMed]

16. Nshizirungu, T.; Rana, M.; Jo, Y.-T.; Park, J.-H. Rapid leaching and recovery of valuable metals from spent lithium ion batteries (LIBs) via environmentally benign subcritical nickel-containing water over chlorinated polyvinyl chloride. J. Hazard. Mater. 2020, 122667. [CrossRef] [PubMed]

17. Matsui, T.; Kitagawa, Y.; Okumura, M.; Shigeta, Y. Accurate standard hydrogen electrode potential and applications to the redox potentials of vitamin C and NAD/NADH. J. Phys. Chem. A 2015, 119, 369-376. [CrossRef]

18. Shih, Y.J.; Chien, S.K.; Jhang, S.R.; Lin, Y.C. Chemical leaching, precipitation and solvent extraction for sequential separation of valuable metals in cathode material of spent lithium ion batteries. J. Taiwan Inst. Chem. Eng. 2019, 100, 151-159. [CrossRef]

19. Gao, W.; Liu, C.; Cao, H.; Zheng, X.; Lin, X.; Wang, H.; Zhang, Y.; Sun, Z. Comprehensive evaluation on effective leaching of critical metals from spent lithium-ion batteries. Waste Manag. 2018, 75, 477-485. [CrossRef]

20. Li, L.; Qu, W.; Zhang, X.; Lu, J.; Chen, R.; Wu, F.; Amine, K. Succinic acid-based leaching system: A sustainable process for recovery of valuable metals from spent Li-ion batteries. J. Power Sources 2015, 282, 544-551. [CrossRef]

21. Chen, G.; Yang, H.; Li, H.; Tong, L. Recovery of cobalt as cobalt oxalate from cobalt tailings using moderately thermophilic bioleaching technology and selective sequential extraction. Minerals 2016, 6, 67. [CrossRef]

22. Bard, A.J.; Faulkner, L.R. Electrochemical Methods: Fundamentals and Applications, 2nd ed.; Harris, D., Swain, E., Robey, C., Aiello, E., Eds.; John Wiley \& Sons, Inc.: New York, NY, USA, 2012; Volume 2, ISBN 0-471-04372-9.

23. Tur'yan, Y.I.; Kohen, R. Formal redox potentials of the dehydro-l-ascorbic acid/l-ascorbic acid system. J. Electroanal. Chem. 1995, 380, 273-277. [CrossRef]

24. Karpushkin, E.A.; Kharochkina, E.S.; Iarchuk, A.R.; Gallyamov, M.O.; Sergeyev, V.G. Hydrothermal transformations of ascorbic acid. Russ. J. Gen. Chem. 2017, 87, 2858-2864. [CrossRef]

25. Mogol, B.A.; Gökmen, V. Kinetics of furan formation from ascorbic acid during heating under reducing and oxidizing conditions. J. Agric. Food Chem. 2013, 61, 10191-10196. [CrossRef]

26. Markevich, E.; Salitra, G.; Aurbach, D. Influence of the PVdF binder on the stability of $\mathrm{LiCoO}_{2}$ electrodes. Electrochem. commun. 2005, 7, 1298-1304. [CrossRef]

27. Verdier, S.; El Ouatani, L.; Dedryvère, R.; Bonhomme, F.; Biensan, P.; Gonbeau, D. XPS study on $\mathrm{Al}_{2} \mathrm{O}_{3}-$ and $\mathrm{AlPO}_{4}$-coated $\mathrm{LiCoO}_{2}$ cathode material for high-capacity $\mathrm{Li}$ ion batteries. J. Electrochem. Soc. 2007, 154, A1088. [CrossRef]

28. Peng, C.; Hamuyuni, J.; Wilson, B.P.; Lundström, M. Selective reductive leaching of cobalt and lithium from industrially crushed waste Li-ion batteries in sulfuric acid system. Waste Manag. 2018, 76, 582-590. [CrossRef]

29. Lee, J.; Kim, S.; Kim, B.; Lee, J. Effect of mechanical activation on the kinetics of copper leaching from copper sulfide (CuS). Metals (Basel) 2018, 8, 150. [CrossRef]

30. Baba, A.A.; Ayinla, K.I.; Adekola, F.A.; Bale, R.B.; Ghosh, M.K.; Alabi, A.G.F.; Sheik, A.R.; Folorunso, I.O. Hydrometallurgical application for treating a Nigerian chalcopyrite ore in chloride medium: Part I. Dissolution kinetics assessment. Int. J. Miner. Metall. Mater. 2013, 20, 1021-1028. [CrossRef]

31. Shin, S.M.; Kim, N.H.; Sohn, J.S.; Yang, D.H.; Kim, Y.H. Development of a metal recovery process from Li-ion battery wastes. Hydrometallurgy 2005, 79, 172-181. [CrossRef]

Sample Availability: Not available.

(C) 2020 by the authors. Licensee MDPI, Basel, Switzerland. This article is an open access article distributed under the terms and conditions of the Creative Commons Attribution (CC BY) license (http://creativecommons.org/licenses/by/4.0/). 